\title{
TESTING TRANSFORMATION AND DECOLONISATION: EXPERIENCES OF CURRICULUM REVISION IN A HISTORY HONOURS MODULE
}

DOI: http://dx.doi.org/10.17159/ 2223-0386/2019/n22a1

\author{
Ian Macqueen \\ University of Pretoria \& \\ Society, Work and Politics Institute, University of the Witwatersrand \\ ian.macqueen@up.ac.za \\ ORCID No: 000-0001-9154-4625
}

\begin{abstract}
This article discusses the revision of a history honours historiography module. It discusses the rationale, methodologies and material used to respond to the imperative of curriculum transformation and decolonisation. The article is titled 'testing transformation and decolonisation' to emphasise the exploratory nature of this revision, but also to underline the challenging nature of teaching new material, which educators have often not been taught themselves. The article draws on the University of Pretoria's 2016 Curriculum Transformation Framework document and narrates the practical challenges of implementing its recommendations. The article also provides a personal perspective of my embrace of calls for transformation and decolonisation of the university, which highlights the continuities I see in these contemporary calls with the historical concerns of the previous generations of progressive South African scholars who similarly called for and worked to realise a decolonisation of knowledge.
\end{abstract}

Keywords: Transformation; Historiography; South African History; Global History; Postgraduate Education.

\section{Introduction}

The excitement of self-discovery, the excitement of shattered certainties, and the thrill of freedom: These are experiences that are closed to white South Africans. The price of control is conformity. But these patterns can be broken. And it is important try to break them. It is important to show the whites they have to gain from a free democratic society. Once cultural preservation and development becomes freed from the preservation of privilege it becomes possible to visualize a society in which cultural identity does not imply exclusivity and fear. Until white South Africans come to understand that present society and their present position is a result not of their own virtues but of their vices; until they come to see world history over the last five hundred years not as the "triumph of white civilization," but simply as the bloody and ambiguous birth of a new technology, and 
until they come to see these things not in the past but in hope for the future, they will not be able to communicate with black people, nor, ultimately, with one another. ${ }^{1}$

Written in the early 1970s by the South African philosopher Rick Turner this short passage provides a succinct description of the heart of an intellectual and practical project in which Turner and a small group of white academics and activists in Durban in the 1970s engaged. In retrospect it is perhaps apt to characterise this as an equivalent White Consciousness that developed in tandem with the emergence of Black Consciousness in South Africa. ${ }^{2}$ Considering recent challenges to the academy by a new generation of black students, it appears the above sentiment remains to be fulfilled if only the audience addressed has changed. While transformation and decolonisation are very much part of the current academic imperatives, they are obviously concerns whose history runs deeper than the last few years. Indeed, part of the emphasis in this article is to present transformation, or decolonisation as it has increasingly been called, as an inherent component of the academic project in South Africa and one in which white academics have played a part, though this must of necessity be a limited one.

This article provides a description of how I responded to transformation or decolonisation in a core honours historiography module. Jasper Knight describes transformation as the process that has been underway since 1994, and which has "included bringing to the fore viewpoints of black history, literature and politics ... with revisionistic descriptions and interpretations of South African historical events". ${ }^{3}$ This process thus interacts with the more recent emphasis on decolonisation and Africanisation that have informed the challenges to tertiary institutions of Fees Must Fall. Siseko Kumalo and Leonhard Praeg emphasise decolonisation to be "the realisation of epistemic justice for the peoples of the global South". ${ }^{4}$ Sabelo J. Ndlovu-Gatsheni adds that decoloniality is "a call for democratization of knowledge, de-hegemonization of knowledge, de-westernization of knowledge, and de-Europeanization of knowledge". ${ }^{5}$

1 R Turner, The eye of the needle: Toward participatory democracy in South Africa (Johannesburg, Ravan Press, 1980), p. 101.

2 I Macqueen, Black consciousness and progressive movements under apartheid (Pietermaritzburg, University of KwaZulu-Natal Pres, 2018).

3 J Knight, "Decolonizing and transforming the Geography undergraduate curriculum in South Africa", South African Geographical Journal, 100(3), 2018, p. 273.

4 S Kumalo and L Praeg, "Decoloniality and justice a priori", Journal of Decolonising Disciplines, 1(1), 2019, pp. 1-9.

5 SJ Ndlovu-Gatsheni, "Decoloniality as the future of Africa", History Compass, 13(10), 2015, p. 492. 
This article is titled "testing transformation and decolonisation" to emphasise the practical challenges of responding to the injunction of decolonisation and transformation of a university historiography curriculum. I have found this to be a challenging and exciting process, which has re-emphasised the need for critical thought and questioning of assumptions. Responding to the need for transformation and decolonisation has been an exciting and creative challenge, in the words of Turner, the rewards have been the "excitement of self-discovery, the excitement of shattered certainties, and the thrill of freedom".

South African universities have been pushed to respond to the need for decolonisation most directly in the Rhodes Must Fall movement of 2015. This article draws on a document that was drafted in response to the 2015 protests, namely the University of Pretoria's Curriculum Transformation Framework document. ${ }^{6}$ The article specifically discusses the practical challenges of implementing the recommendations of this policy.

\section{A personal view of transformation}

It is beneficial at this point to lay bare the journey that has led me to embrace transformation and decolonisation of the curriculum but also to stress the continuities of this contemporary call with the progressive thrust of radical scholars in the South African academy, represented in this article by Turner. It was to these scholars that I owed a critical part of my personal transformation.

I was born in Johannesburg in the early 1980s and the transition to democracy informed my early and secondary schooling - I was in Standard Five in Newcastle, in the then Northern Natal, when our school received its first black children, although only a very small number. My introduction to high school was a shock. In my first year as an innocent "Standard six" learner I witnessed running battles where black students were targeted and badly beaten up by a core of aggressive, senior white, predominantly Afrikaans students. This seemed to subside as my high school years continued, but there were more confrontations between white and Taiwanese students, who stood their ground and did not allow themselves to be intimidated.

6 University of Pretoria, "Reimagining curricula for a just university in a vibrant democracy: Work stream on curriculum transformation at the University of Pretoria" (available at https:/www.up.ac.za/media/shared/9/ HumPdf\%20docs/up-curriculum-transformation-framework-final-draft_23may2016_1.zp89110.pdf, as accessed on 21 August 2019). 
I had the reflex opinions of what I would deem the "average" white English- speaking South African. "We" had brought development to Africa. I recall lampooning Umkhonto we Sizwe veterans who paraded on the television, sneering at the sincerity of Archbishop Tutu crying at the Truth and Reconciliation Commission hearings and teased my brother that he would marry "Susie Mtwetwe" one day. Afrikaners were "rock spiders" or "Dutchmen".

After finishing matric in Durban and a gap year in the United Kingdom I entered the University of Natal in 2002 (renamed the University of KwaZulu-Natal in 2004 after being merged with the University of DurbanWestville). The late Professor Jeff Guy taught the first year students in a module for which we had to purchase Jared Diamond's Guns, Germs and Steel, a text that rejected essentialist explanations of human development (Europeans were inherently more intelligent) and located the differential outcomes of global wealth distribution in the random chance of geography ${ }^{7}$. Guy made a strong impression, as a wiry, stalking intellect, a "communist", a term that in my mind was associated with a vague nefarious force up until that point, but in Guy was grounded above all in a quest to understand. The second year featured the passionate lecturing of Dr Catherine Burns in the "Law and Society" course, for which students had to prepare research assignments of 8000 words. This was an exciting intellectual challenge. In the third year the focus shifted to the "foreign country" of South African history where I began to uncover a past of which I had no knowledge, and of which school history had provided only a caricature. This new world included the 1913 Land Act, the role of mining compounds in garrisoning black labour, and South Africa's Prussian route to development sparked by its mineral discoveries, all dominant insights of revisionist South African historiography, made between 1970 and $1974 .{ }^{8}$ Suddenly, the reflex notions that had guided me, quite comfortably, through South African reality until that point broke down and were rendered dangerously simplistic.

At university the Student Christian Association (SCA) enabled me to attend a conference at the University of Fort Hare. The experience of being one of a handful of white students among a majority of black students left an impression on me, as well as the feeling of visceral hostility I experienced in the vicinity of Alice. I can still remember the central motif

7 J Diamond, Guns, germs and steel: A short history of everybody for the last 13,000 (London, Vintage, 1998).

8 U Dhupelia-Mesthrie, "AA blast from the past': The teaching of South African History at an apartheid university, 1960s-1980s", South African Historical Journal, 42, 2000, p. 60. 
of that conference. This was another foreign country. The experience of one to one Bible study with the staff worker of the Young Men's Christian Association (YMCA), Danellia Daniels, a Coloured female, was also significant. She openly identified with the "Struggle" and embraced her faith together with a political and social justice awareness, whilst at the same time giving pastoral care to middle-class white students as part of her broader mandate. Something began to further be dislodged.

Honours study in the Department of History was a new world of intellectual discovery. In addition to its academic staff the department was comprised of a dynamic postgraduate cohort who now staff many South African university history departments. Dr Keith Breckenridge's African States module contextualised South Africa in broader African history. Catherine Burns' Theory and Methods course emphasised the dynamic relationship between history writing and theory, such as the work of Jacques Derrida and Michel Foucault, and the implications their ideas had for historical research. The Wednesday afternoon seminars in the "Shark Tank" were the weekly highlight. The passionate investment of academics in their work perhaps was the most abiding impression. My honours dissertation on Archbishop Alphaeus Zulu, supervised by Dr Vukile Khumalo, exposed me to the frustrations, tragedies and fight for dignity of the amaKholwa, and exposed me to a prominent black clergyman who rose to the heights of acting as president of the World Christian Council (WCC) and yet retained his Zulu identity, but became embroiled in the vicissitudes of Inkhata and the Zululand Bantustan in the 1980s. Two studies that guided my research were Tim Couzen's The New African: A Study of the Life and Work of H.I.E. Dhlomo and David Attridge's Rewriting Modernity: Studies in Black South African Literary History. ${ }^{9}$ It was of course a sad irony, that this department that was so critical to my own transformation was to be targeted after 2006 by a transformation agenda and dispersed to the benefit of other universities around the country.

One could not be an undergraduate at the university and not encounter the memory of Rick Turner. I recall, wrongly or not, a small portrait of him in the Student Hall where we wrote exams in first year. I was drawn to understanding who he was and what his relationship with Steve Biko was, once a student at the university's medical school in the late 1960s.

9 T Couzens, The New African: A study of the life and work of H.I.E. Dhlomo (Johannesburg, Ravan Press, 1985); D Attwell, Rewriting modernity: Studies in black South African literary History (Athens, Ohio University Press, 2006). 
The question of the relationship of Turner and Biko informed my doctoral research at the University of Sussex under the supervision of Saul Dubow and Alan Lester and continued the process of personal transformation that had begun as a student. My research provided a fascinating window into what can now be called a push for decolonisation by the Black Consciousness Movement, as well as the response of progressive whites to this challenge. ${ }^{10}$

I returned to South Africa in 2012 to a postdoctoral fellowship in the Society, Work and Development Institute at the University of Witwatersrand. The institute had been set up in the 1980s by Eddie Webster, a sociologist who had been one of many scholars to take the intellectual baton from Rick Turner. Under the mentorship of Professor Karl von Holdt I set about publishing the findings of my doctorate and beginning the process of turning it into a book, published in 2018 by UKZN Press. ${ }^{11} \mathrm{I}$ began at the University of Pretoria in 2015.

\section{Transformation at the University of Pretoria}

2015 was of course the year of Rhodes must Fall/Fees must Fall. It was midway through the second semester when the university was closed on 21 October 2015. One of the local leaders was taking a module in the Department of Historical and Heritage Studies and was simultaneously in court prosecuted on charges of public violence. ${ }^{12}$ In response to the nationwide strikes, and after the University of Pretoria had reopened its doors, the institution held a lekgotla in March 2016, chaired by former justice of the Constitutional Court, Yvonne Mokgoro, out of which emerged the curriculum transformation framework document "Reimagining Curricula for a Just University in a Vibrant Democracy". The process was driven by Professor Norman Duncan, the Vice-Principal: Academic, a psychologist by training, with speciality in critical race theory. Prof Christi van der Westhuizen was also employed by the university in 2015 with a 50 percent transformation mandate.

Overall the university put in place three work streams to tackle the broad goal of transformation, namely: curriculum, language policy, and institutional culture. For each of the work streams the intention was to

10 I Macqueen, "Re-imagining South Africa: Black consciousness, radical christianity and the New Left, 1967-1977”' (Doctoral thesis, University of Sussex, 2011).

11 I Macqueen, Black consciousness and progressive movements under apartheid (Pietermaritzburg, University of KwaZulu-Natal Press, 2018).

12 For a detailed history see "University of Pretoria 2015-2016 Student Protests Timeline" (available at https:// www.sahistory.org.za/article/university-pretoria-2015-2016-student-protests-timeline, as accessed on 14 September 2019). 
gain input from students, academic and support staff. A team drafted the curriculum transformation framework, made up of Prof van der Westhuizen (Associate Professor, Department of Sociology, Faculty of Humanities), Prof James Ogude (Director of the Centre for the Advancement of Scholarship), Prof Derick de Jongh, (Director of the Albert Luthuli Centre for Responsible Leadership), Dr Joel Modire (Senior Lecturer, Department of Jurisprudence, Faculty of Law), and Dr Ndukuyakhe Ndlovu (Senior Lecturer, Department of Anthropology and Archaeology, Faculty of Humanities).

Christi van der Westhuizen recalls that the transformation document was explicitly informed by the emergent literature on decolonisation and the response the team received from the university community was that this language was unfamiliar. This led the task team to embark on a roadshow, where they presented the document to all the major faculties, except the Gordon Institute of Business Science, where they were able to take feedback and adapt the framework document. The University of Pretoria formally adopted the Curriculum Transformation Framework in 2016. In retrospect, Van der Westhuizen saw the process as one of the most comprehensive and democratic processes initiated by a South African university in the wake of Fees must Fall. ${ }^{13}$ The framework document outlined four drivers that were seen to be vital for meaningful transformation of curricula, namely: "responsiveness to social context"; "epistemological diversity"; "renewal of pedagogy and classroom practices"; and "an institutional culture of openness and critical reflection". ${ }^{14}$

The first driver of "responsiveness to social context" called for the retrieval and foregrounding of "historically and presently marginalised narratives, voices and subjugated knowledges and an acknowledgement of indigenous knowledge systems hitherto repressed in the South African context". Such local knowledge systems needed to be characterised as "sites of contestation". The document also drew attention to the impact of "race, class, gender, sexuality, culture and other categories of identification and disadvantage" and their impact on disciplines. The aim of such responsiveness to context, was for the purpose of positive social transformation, and the framework document called for university education to produce "thoughtful citizens"

13 C van der Westhuizen, skype interview with author, 22 August 2019.

14 University of Pretoria, "Reimagining curricula for a just university in a vibrant democracy: Work stream on curriculum transformation at the University of Pretoria" (available at https://www.up.ac.za/media/shared/9/ HumPdf\%20docs/up-curriculum-transformation-framework-final-draft_23may2016_1.zp89110.pdf, as accessed on 21 August 2019). 
that "display critical thinking" and "critical literacy". It was important, the writers urged, to engage the "life worlds that students inhabit by linking teaching material to current affairs and cutting -edge research." It lastly called for a foundational course on South African history "for all first-year undergraduate students", a requirement that perhaps showed optimism despite the complexities that such a foundational, and therefore instrumentalist, use of history could pose..$^{15}$

The document described "Epistemological diversity" as the need to bring "marginalised groups, experiences, knowledges and worldviews emanating from Africa and the Global South to the centre of the curriculum" and in the process "challenging the hegemony of Western ideas and paradigms and foregrounding local and indigenous conceptions and narratives". The framework further emphasised the need for a process of "excavating and recuperating African, Latin American and Asian knowledges and practices that have been devalued and marginalised". It also addressed the need to engage the histories of disciplines themselves and the prioritisation of certain forms of knowledge over others. ${ }^{16}$

The third driver, "Renewal of pedagogy and classroom practices", called for the need for responsiveness and reflexivity in pedagogical practice and emphasised the importance of scaffolding between levels, recognising the "invisibility of certain groups", being open to technological innovation in teaching, incorporating "inquiry-led teaching and learning", creating a "robust" but "affirming and sensitive" space that promotes the learning of key competencies.

The last driver, "An institutional culture of openness and critical reflection", spoke of the need to address "the hidden curriculum", "found in the spaces, symbols, narratives and embedded practices that constitute the university and in the diversity, or lack thereof, of the staff and student cohort". It called for diversity in employment, as well as "reviewing and redefining the identity of the university", in the process "dismantling institutional hierarchies and reviewing organisational processes and practices to enable collegiality, dialogue and democracy at all levels of the

15 University of Pretoria, "Reimagining curricula for a just university in a vibrant democracy: Work stream on curriculum transformation at the University of Pretoria" (available at https:/www.up.ac.za/media/shared/9/ HumPdf\%20docs/up-curriculum-transformation-framework-final-draft_23may2016_1.zp89110.pdf, as accessed on 21 August 2019), p. 2.

16 University of Pretoria, "Reimagining curricula for a just university in a vibrant democracy: Work stream on curriculum transformation at the University of Pretoria" (available at https:/www.up.ac.za/media/shared/9/ HumPdf\%20docs/up-curriculum-transformation-framework-final-draft_23may2016_1.zp89110.pdf, as accessed on 21 August 2019)., pp. 3-4. 
university". Lastly, it prioritised the need to critically re-evaluate "spaces and symbols to situate the university in its historical, cultural and global landscapes". ${ }^{17}$

The remainder of this discussion uses the curriculum transformation framework document to assess my attempts to revise a historiography module. These revisions were not made firstly as a response to the framework document, but rather in an effort to "update" the module. The curriculum transformation framework document is thus used as a heuristic and diagnostic yardstick for the revisions of the historiography module.

\section{Transforming a Historiography module}

The rationale behind the core honours module is to ground history students in a broader disciplinary conversation. The intention, though often unrealised, is that students will use this introduction to critically ground their research theses in the wider disciplinary context. At the University of Pretoria, two core modules split historiography from historical methodology, which on the one hand examines the historical development of the discipline and on the other hand, explores the theoretical and methodological challenges of the discipline. There are often synergies between the modules, although this has not been explicitly planned as such. The historiography module was split into two segments, the first introducing students to the development of Western historiography and the second segment an introduction to South African historiography.

I initially received the South African historiography section, which I cotaught with Dr Glen Ncube, while Professor Alois Mlambo taught the first segment. South African historiography took up five weeks of a twelveweek module. In its original form the introduction to the module read as follows: ${ }^{18}$

The aim of this module is to portray by means of certain examples the development of history as a science from its origins in the 19th century to the present. This goes for both Western and South African historiography. The speculative philosophy of history aims at a universal-historical approach to history which reveals the pattern of thought and structure of thought of the presenters.

17 University of Pretoria, "Reimagining curricula for a just university in a vibrant democracy: Work stream on curriculum transformation at the University of Pretoria" (available at https://www.up.ac.za/media/shared/9/ HumPdf\%20docs/up-curriculum-transformation-framework-final-draft_23may2016_1.zp89110.pdf, as accessed on 21 August 2019).”, p. 5.

18 GES 701 Study Guide, 2015. 
The discussion will return to this introduction in more detail at a later point. The section on South African historiography gave students an introduction to separate "schools" of South African historiography. It began with "GM Theal as representative of colonial white-centric South African historiography". The second week moved to explore "The development and characteristics of Afrikaner historiography, 1877-1990 \& Gustav Preller and FA van Jaarsveld as representatives of Afrikaner historiography". The third week explored "Liberal historiography in South Africa until the early 1960's" using Leonard M Thompson as a case study. The fourth week engaged the emergence of the "radical school of South African historians" through its "main themes, ideological principles and characteristics". The final, fifth week, was presented as a question: "While the views of the first black writers on South African history were led by a Christian liberalhuman perception, black nationalistic writers after 1948 interpreted their past as a struggle for freedom and emancipation." Discuss critically." As far as I have been able to determine this is not a quote from a published source. The key texts of the module were both published in 1988, namely Christopher Saunders' The Making of the South African Past ${ }^{19}$ and Ken Smith's The Changing Past. ${ }^{20}$ In addition there were various works of FA Van Jaarsveld. ${ }^{21}$ There was a wider range of lesser-used authors and sources, but of these, of which there were approximately 20 sources, not one was a black author, and only one source explicitly dealt with black historical perceptions, written by a European scholar. ${ }^{22}$ The need for transformation and decolonisation could not have been more strongly apparent.

Our initial revision of the module in 2015 and then in 2016 took place at the same time as Fees Must Fall and the subsequent institutional response from the University of Pretoria. The first and most apparent need was to update the sources and introduce black authors, such as Magema Fuze, ${ }^{23}$

19 C Saunders, The making of the South African past: Major historians on race and class (Cape Town, David Philip, 1988).

20 K Smith, The changing past: Trends in South African historical writing (Johannesburg, Southern Book Publishers, 1988).

21 Among them, FA Van Jaarsveld, Geskiedkundige verkenninge (Pretoria, Van Schaik, 1974); FA Van Jaarsveld, Omstrede Suid-Afrikaanse verlede: Geskiedenis ideologie en die historiese skuldvraagstuk (Johannesburg, Lex Patria, 1984); FA Van Jaarsveld, Afrikanergeskiedskrywing: Verlede, hede en toekoms (Johannesburg, Lex Patria, 1992).

22 WRL Gebhard, Shades of reality: Black perceptions of South African History, African Literatures in English 3 (Essen, Blaue Eule Verlag, 1991).

23 M Fuze, The black people and whence they came: A Zulu view (Pietermaritzburg, University of Natal Press, 1979). 
Sol Plaatje, ${ }^{24}$ Bernard Magubane, ${ }^{25}$ Premesh Lalu, ${ }^{26}$ Jabulani Nxumalo ('Mzala') ${ }^{27}$ as well as works on black history by white scholars such as that of Edward Roux ${ }^{28}$ and Dora Taylor. ${ }^{29}$ Furthermore, the two volumes of the new Cambridge History of South Africa ${ }^{30}$ were used. While we retained the basic approach of "schools" of South African historiography we moved what we now called "Black and anti-colonial history" to the third week, thus according it more relative importance than where it was in the final week. In addition, we included two additional weeks on "Postmodernism" and "New Voices/New Directions", to reflect what we felt were some of the major recent impacts on South African historiography and to give the students a sense of new trends that were emergent in the discipline, of which they were part.

It was apparent, however, that including additional sources to the existing structure was inadequate. As it stood, the South African historiography module in effect privileged English and Afrikaner histories, which took four out of five of the original themes. To challenge this bias the module was changed in 2017 to engage with the development of South African historiography chronologically, putting works of history by different "schools" together in comparative perspective. In theory this meant that students would be free to explore a historical approach or historian in context. The rationale for this approach was explained to the students as follows: ${ }^{31}$

There are distinct advantages of placing different approaches to South African history in comparative perspective within a particular historical context, one of which is that no particular approach can be taken to speak completely for that period. The other is that it gives a fuller sense of how contested the past is. You will come to see that some of the readings assume relatively neat divisions of South African history writing, for example that of "liberal" versus "radical" interpretations of the past,

24 S Plaatje, Native life in South Africa (Johannesburg, Ravan Press and Witwatersrand University Press, 1982).

25 B Magubane, "Whose memory - Whose History? The illusion of liberal and radical historical debates", HE Stolten, History making and present day politics (Uppsala, Nordiska Afrikainstitutet, 2007), pp. 251-279.

26 P Lalu, The deaths of Hintsa: Post-apartheid South Africa and the shape of recurring pasts (Cape Town, HSRC Press, 2009); P Lalu, "When was South African history ever postcolonial?" Kronos, 34 (November 2008), pp. 267-281.

27 J Nxumalo, "The national question in the writing of South African history: A critical survey of some major tendencies", Working Paper, 22, The Open University, n.d, pp. 36-59.

28 E Roux, Time longer than rope. A history of the black man's struggle for freedom in South Africa (Madison, WI; London, University of Wisconsin Press, 1964).

29 N Majeke (D Taylor), The role of missionaries in conquest (Johannesburg, Society of Young Africa, 1952).

30 C Hamilton, BK Mbenga and R Ross, The Cambridge History of South Africa: Volume 1: From early times to 1885 (Cambridge, Cambridge University Press, 2009); R Ross, A Kelk and B Nasson, The Cambridge History of South Africa: Volume 2, 1885-1994 (Cambridge, Cambridge University Press, 2011).

31 GES 701 Study Guide (2017). 
whereas others reject these divisions as contrived and self-declared. The aim of each session will be to distinguish differing interpretations of the South African past alongside each other in their historical context.

To achieve this aim required an active search for alternative sources, and a move away from the "standard" works on South African historiography, some of which were listed above. The challenge, though, was that the "schools" of historical thinking approach still dominated discussions and students, especially academically weaker students tended to resort to the "standard works" that were easily accessible on the library shelves and paraphrase their perspectives and arguments. In addition to the initial set of black history works further new studies were included, especially research by black scholars, such as Hlonipha Mokoena, ${ }^{32}$ Vukile Khumalo, ${ }^{33}$ Sifiso Ndlovu, ${ }^{34}$ and Archie Dick. ${ }^{35}$

As a result of this revision, the South African historiography module now looked as follows. The first week began under the title "Recovering Lost Voices" that discussed the challenges of pre-colonial history; the second week, as part of "First Histories" examines the first published accounts of the history of the region. In the third week, "History writing and the Forging of Identities c1800 to 1930s", explores the role of histories in the consolidation of new identities in the fledgling South African state and the ways in which narratives of the past played a legitimating function for competing political claims. The fourth week covers, "The Professionalization of History Writing c. 1930s to 1960s", which allows for discussion of the consolidation of both Afrikaner histories, and the emergence of liberal historiography, as well as forms of anti-colonial history that were emergent at the time. The fifth week moves to explore "History and the Anti-apartheid Struggle, 1960 - 1990", a topic which includes the so-called "liberal-radical" debate, but also seeks to consider this debate in the broader role of history in the struggle, exploring the contestation between official histories and counter-narratives, which gave the vocation of the historian a particular power. In week six, the topic has been broadened to address "History, post-apartheid and postmodern",

32 H Mokoena, Magema Fuze: The making of a "Kholwa" intellectual (Pietermaritzburg, University of KwaZulu-Natal Press, 2011).

33 V Khumalo, "Ekukhanyeni letter-writers: A historical inquiry into epistolary network(s) and political imagination in KwaZulu", K Barber, Africa's hidden histories: Everyday literacy and making the self (Bloomington and Indianapolis, Indiana University press, 2006), pp. 113-142.

34 S Ndlovu, African perspectives of King Dingane kaSenzangakhona: The second monarch of the Zulu kingdom (Cham, Switzerland, Palgrave Macmillan, 2017).

35 A Dick, The hidden history of South's book and reading cultures (Toronto, University of Toronto Press, 2012). 
covering the crisis in the discipline after the sureties of the anti-apartheid struggle and the challenge to the empiricism of both liberal and radical histories. The final week broadens the discussion to address "New Voices and New Directions". The material is covered with weekly seminars that students prepare for, with preselected presenters leading the discussion each week based on their research paper on that week's theme. The presentation and the research paper itself are then graded by the module facilitator.

To evaluate the new structure in terms of the curriculum transformation framework's four drivers, it seems that at least "Responsiveness to social context" and "Epistemological diversity" have been responded to, though admittedly not fully met, by the restructuring and inclusion of new material. The revisions, through an inclusion of more voices, a chronological approach, and an emphasis on the contested nature of the past, have aimed to recover "marginalised narratives, voices and subjugated knowledges" and engage in a diversity of knowledge about the past. The drivers of "Renewal of pedagogy and classroom practices" and "An institutional culture of openness and critical reflection" both refer to pedagogical challenges that seem to me to be of a different scale and challenge. In terms of scaffolding and preparation for postgraduate studies, this must begin at undergraduate level, which our department has already recognised and attempted to address through the inclusion of more independent research projects. Both drivers also speak to a dynamic that is only addressed through demographic diversity, and it is apparent that conversations in the postgraduate spaces remain limited if dominated by one group of people (in our case, postgraduate studies are still dominated by white students).

Several further challenges remain, which are discussed in turn here. The first quandary has been the question of whether previous standard historiographical works should still be included in reading lists? As noted, often (weaker) students tend to paraphrase these older works, which then replicates their voice and militates against the type of conversation and debate intended. Secondly, there are challenges that the discipline faces in teaching resources. The standard works on historiography have been noted and the alternative is a wider and more challenging search for voices and sources. Available black voices in English are limited, which flags the challenge of recovering African historical texts in African languages, a call that has been made by scholars such as Sifiso Ndlovu. Another instructive example is taken from an article by Helen Bradford and Msokoli Qotole, 
who in response to a statement made by Hans Erik Stolten that "South Africa's historiographical tradition is characterised by the absence of black historians", ${ }^{36}$ note that: ${ }^{37}$

Even if 'historian' is equated with 'published historian', black historians of South Africa have probably far outnumbered their white counterparts. Typically, however, they published in African languages and in the popular media arenas which most scholars have yet to explore. It is not lack of education that has barred blacks from being recognized as historians. It is rather lack of knowledge of African languages among most scholars who pronounce on South African history.

One way of responding to the challenge of Bradford and Qotole would be through an engagement with such African 'popular media arenas' through new avenues that have become available. The African Newspaper series offered by the American company Newsbank, for example, offers a fully searchable internet database of popular media content from as far back as 1789 in some cases. However, this raises the need for translation of these texts into English, as well of course as the greater challenge of learning African languages that historians should engage with. In the immediate interests of students, especially international students who attend South African universities in growing numbers, it is imperative these texts can be read in English.

Bradford's and Qotole's article is a fascinating example of the rewards that this approach gives, which translates the debate between the Xhosa historian William Wellington Gqoba and a retired colonial official, Charles Brownlee, on the history of the so-called Xhosa Cattle-Killing in the pages of a monthly Christian newspaper, Isigidimi SamaXosa. As they observe: "if isiXhosa categories start outweighing those in officialdom's accounts, then everything may change: the object of analysis, the period of concern, the region of relevance, the social forces underpinning the catastrophe". However, they also note that while "such African-language accounts illuminate much, formidable linguistic barriers to their full appreciation nonetheless exist". ${ }^{38}$ The linguistic barriers of translation are a matter of priority of course; consider the commitment of scholars of other regions of the world to the study of orthographies of their old languages. Thus, the excuse of impracticality or difficulty cannot be sustained.

36 HE Stolten, "History in the new South Africa: An introduction", HE Stolten, History making and present- day politics: The meaning of collective memory in South Africa (Uppsala, Nordiska Afrikainstitutet, 2007), p. 8.

$37 \mathrm{H}$ Bradford and M Qotole, "Ingxoxo enkulu ngoNongqawuse (a great debate about Nongqawuse's era)", Kronos, 34(1), 2008, p. 66.

38 H Bradford and M Qotole, "Ingxoxo enkulu ngoNongqawuse...", Kronos, 34(1), November, p. 70. 
In 2018 the first half of the module came under scrutiny. Initially the module looked as follows: it began with a seminar on Leopold von Ranke "the founder of the modern scientific historiography", and moved to consider in consecutive weeks: "The Marxist view of history as influenced by the Karl Marx and Friedrich Engels", "The French Annales School (1900 - 1945)", "The Christian vision of history, as determined by the Old and New Testament and St. Augustine's De Civitate Dei", "The Enlightenment's doctrine of progress", "Oswald Spengler's philosophy of cyclic downfall", and lastly "Arnold Toynbee's view of genesis, growth, breakdown and disintegration of civilizations". The module evidently was an effective overview of significant trends of Western historiography. It was also a prime example of Western-centric, or perhaps even a Eurosolipstic (there is nothing noteworthy outside of Europe/West) approach to historiography.

The revision of this part of the module was initially guided by a 50-page article by Canadian scholar, Daniel Woolf. The revealing premise of Woolf's historiography is that the global dominance of Western historiography reflected European military and economic dominance, and thus was not a product of inherent intellectual superiority. In Woolf's own words: ${ }^{39}$

A consequence of the global dominance of Western academic historical practices is that not just history, but historiography, has been "written by the victors." None of the major histories of historical writing produced in the last century addresses other historiographical traditions, undoubtedly in part owing to linguistic difficulties. This has produced a thoroughly decontextualized and celebratory grand narrative of the rise of modern method that has only been challenged in recent years. It is thus critical that any new survey of historical writing not only pay serious attention to non-Western types of historical writing (and indeed to nonliterary ways in which the past was recorded and transmitted), but that it also steer clear of assuming that these were simply inferior forms awaiting the enlightenment of modern European-American methodology.

It is evident that Woolf's approach to historiography is congruent with the broader imperative of decolonisation for "epistemic justice", that is, a fairer acknowledgement of forms of historical consciousness in peoples around the world.

Drawing on Woolf the new structure allowed students to begin with the fundamental question of "What is Historiography and why is it important?" Over the next three weeks students then engaged with what

39 D Woolf, "Historiography", MC Horowitz, New dictionary of the History of ideas, 1 (New York, Scribners, 2005), p. xxxv 
Woolf describes as the major traditions of historiography respectively, Chinese, Islamic and Western. Each of these traditions is examined in a separate week. Woolf is careful to qualify his distinction of "major" and "minor" traditions, emphasising that the former are determined to be major "in terms of their international scope, longevity, and influence" and is thus not a judgement on their quality. ${ }^{40}$ In the fifth week, we cover four of the five minor traditions Woolf discusses, namely "Ancient Indian, precolonial Latin American, East and Southeast Asia" historiographies. Due to our context, we spend the following week covering African historiography and conclude the first part of the module by reflecting on the approach of "Global history", of which Woolf's work is an example, as evidenced by the development of his article into a book published six years later. ${ }^{41}$

Clearly the main achievement of the revision of the module, was in realising a far greater degree of "epistemological diversity" than was present before. It could even be argued that epistemological diversity has been prioritised to the point that engagement with different historiographical traditions becomes superficial - how can one traverse the depth and scope of any of the major traditions in a single seminar? As such a student who has passed through our historiography module now, would not be able to match a student from another university, who has spent six weeks studying the development of historiography in its European form. It must further be admitted, that the authors covered in European historiography are much more widely-known, and thus easier to deploy in footnotes, as students seek to publish their work.

The rewards from the approach were, however, apparent. Firstly, students expressed great excitement in being exposed to other historiographical traditions. For many, it was their first engagement with Chinese history, not to mention Chinese historiography. Engaging with a historiographical tradition, several thousand years old, that had developed mostly independently and often ahead of Europe, was a helpful corrective of the Eurocentrism of our thinking, even discussions that attempted to move beyond Europe. Furthermore, our session on Western historiography questioned what exactly Europe and "the West" was? Was it Roman or Greek, or "transalpine" as one author who resorted to geographical

40 D Woolf, "Historiography", MC Horowitz, New Dictionary of the History of Ideas, 1, p. xxxv.

41 D Woolf, A global history of history (Cambridge, Cambridge University Press, 2011). 
boundaries did? ${ }^{42}$ Despite, Woolf's careful emphasis on the basis of his division of historiography into "major" and "minor" traditions, there was strong criticism of this approach, with one student in particular emphasising the way in which each fed into and informed the other. Our final discussion looked at Global History as a corrective to the imbalance of historiographical voices, but students pointed to the way in which Global History (represented by scholars such as Woolf) was still dominated by scholars from the West.

To return to the driver of "Renewal of pedagogy and classroom practices" the seminar format already provides for a great amount of student participation and direction. In addition, a graded online discussion forum with starter questions prior to the seminar worked well as a way of helping students prepare and to get a sense of what students thought of the readings and the topic for the week. This has been a helpful exercise, and students themselves often refer to the comments they made on the online forum, which they elaborate on in the seminar. 2019 was the first year that included a group work element, where students would share a weekly topic and were required to give a combined presentation. As a result, this allowed them to break down the topic into manageable segments, but also exposed students to the broader concerns of that week.

Lastly, to return to a point made already, it has been apparent that curriculum revision has to occur alongside demographic diversity and that honours seminars are critically denuded if comprised of only white students. In this respect, I am aware of my own limitations as a facilitator of these types of discussions as a white, male lecturer. In addition, gender representivity remains an avenue for further development in the module, and it is apparent that the quest for epistemic diversity of voices was conducted primarily through the lens of race rather than gender.

\section{Concluding thoughts}

The intention of this article has been to reflect on the revision of a historiography honours module in terms of the imperatives of transformation and decolonisation. It is therefore intended to be a candid account of what such a revision has entailed. The article has also sought to establish continuities in the concerns of South African historical scholarship that

42 JGA Pocock, "Western historiography and the problem of 'Western' history", Initiative for an "Alliance of Civilizations", Workshop on "What is Civilization", United Nations (available at https:/www.unaoc. org/repository/9334Western $\% 20$ Historiography $\% 20$ and $\% 20$ Problem $\% 20$ of $\% 20$ Western $\% 20$ History $\% 20$ -\%20JGA\%20Pocock.doc.pdf, as accessed on 10 September 2019). 
are congruent with current calls for transformation and decolonisation and which should not be disregarded. This is of course a limited exercise and the article aims to generate discussion on how to further improve historiography offerings at South African universities and to respond to the concerns raised, such as by the University of Pretoria's curriculum transformation framework document. 